\title{
Study of Xanthine Oxidase Activity in Sera of Iraqi Children with Nephrotic Syndrome
}

\author{
Vyan Asad Qadir ${ }^{1}$, Sardar Nouri Ahmed ${ }^{2 *}$, Dler Rostum Ali ${ }^{2}$ \\ ${ }^{1}$ Department of Chemistry, Faculty of Science and Health, Koya University, Koy Sanjaq, Iraq \\ ${ }^{2}$ Department of Clinical Biochemistry, College of Medicine, Hawler Medical University, Erbil, Iraq \\ Email: ^Sardarna2007@yahoo.com
}

How to cite this paper: Qadir, V.A., Ahmed, S.N. and Ali, D.R. (2018) Study of Xanthine Oxidase Activity in Sera of Iraqi Children with Nephrotic Syndrome. Journal of Biosciences and Medicines, 6, 126-135. https://doi.org/10.4236/jbm.2018.65014

Received: March 27, 2018

Accepted: May 21, 2018

Published: May 24, 2018

Copyright ( 92018 by authors and Scientific Research Publishing Inc. This work is licensed under the Creative Commons Attribution International License (CC BY 4.0).

http://creativecommons.org/licenses/by/4.0/

\section{cc) (i) Open Access}

\begin{abstract}
Introduction: To investigate the relationship of xanthine oxidase activity with nephrotic syndrome disorder in children, and the optimization of the enzyme activity conditions in the disorder. Material and methods: Sera of children with nephrotic syndrome (NS) (60 samples) were obtained from Central Child Teaching Al Karama Hospital (CCTAH), from $2^{\text {nd }}$ Mar. 2013 to $28^{\text {th }}$ Feb. 2014. Sera of the patients were assayed for xanthine oxidase (XO) activity using colorimetric absorbance technique. The obtained results were compared with the enzyme activity of normal children (70 samples) as control. Results and conclusions: The results revealed a significant $(\mathrm{P}<0.001)$ elevation in $\mathrm{XO}$ activity in serum of nephrotic syndrome $(0.12 \pm 0.06 \mathrm{IU} / \mathrm{L})$ compared with that of normal subjects $(0.05 \pm 0.009 \mathrm{IU} / \mathrm{L})$, showing an elevation of $(70 \%)$ in XO activity (about $2 / 3$ ) that of normal group. Factors influencing $\mathrm{XO}$ activities were also studied and showed that $\mathrm{XO}$ activity is a $\mathrm{pH}$ dependent. Significant elevation $(\mathrm{P}<0.001)$ was found in uric acid level in sera of NS patients $(497.52 \pm 3.21 \mu \mathrm{mol} / \mathrm{L})$ compared with that in normal group $(298.12 \pm 1.70 \mu \mathrm{mol} / \mathrm{L})$. Elevation was found in urea level in sera of NS patient $(10.69 \pm 7.55 \mathrm{mmol} / \mathrm{L})$ compared with that of normal group $(4.57 \pm 1.27$ $\mathrm{mmol} / \mathrm{L}$ ). It was appeared, there is a role of XO activity in the pathogenesis of endothelial injury during glomerular lesion in NS and that was confirmed by comparing XO activity and other related conditions with the activity of normal volunteers.
\end{abstract}

\section{Keywords}

Xanthine Oxidase, Urea, Uric Acid, Nephrotic Syndrome

\section{Introduction}

Nephrotic syndrome (NS) is a collection of syndromes due to kidney damage. 
This includes protein in the urine, low blood albumin levels, high blood lipids, and significant swelling. The annual incidence of NS in children in USA and in Europe has been estimated to be 1 to 7 per 100,000 children, with a cumulative prevalence of 16 per 100,000 children [1] [2]. Nephrotic syndrome in children can be classified according to three groups: secondary, congenital and infantile, and idiopathic. Idiopathic nephrotic syndrome is the most frequent form of NS in children representing more than $90 \%$ of cases between 1 and 10 years of age and 50 percent after 10 years of age [2]. In NS, the kidneys let the protein leak out in the urine. When this happens, the water in the blood escapes from blood vessels and capillaries into the tissues of the body, which produce swelling (edema), i.e., kidneys become inflamed. Any swelling will be made worse if the kidneys try to hold more salt than they should to make up for losing the protein. Minimal change disease is the most common cause of NS in children, accounting for $80 \%$ of all cases in children aged 4 to 8 years; it is also responsible for $20 \%$ of all cases in adults [3] [4]. The hallmark of minimal change disease is the presence of normal-appearing glomeruli on light microscopy of a renal biopsy specimen but effacement of the foot processes of the epithelial cell on electron microscopy [5]. The multiplicity of etiology factors, associated conditions, underlying pathology, and pathologenesis makes it difficult to review NS without encompassing all of the diseases that constitute the general group of glomerular disease indeed, except for those processes that rapidly destroy the entire nephron population, and virtually any glomerular lesion may be associated with proteinuria of sufficient magnitude to result in hypoalbuminemia and thus set into motion of the pathophysiologic processes responsible for the constellation of findings we call the NS. Proteinuria arising from defects in glomerular permeability can result from abnormalities in the charge selective or size-selective barrier [6] [7] [8]. Xanthine oxidase (XO) is defined as an enzyme activity (EC, 1.1.7.3.2) from class oxidoreductase and has 2 flavin molecules (bound as FAD), 2 molybdenum atoms and 8 iron atoms bound per enzymatic unite [9] [10]. XO, a form of oxidoreductase that generates reactive oxygen species (ORS), which affect kidney arteries and increase blood pressure and ultimately damage kidney cells [11], is an enzyme that catalyzes the oxidation of hypoxanthine to xanthine and can further catalyze the oxidation of xanthine to uric acid. Uric acid is released in hypoxic conditions. In human and higher primates, uric acid is the final oxidation (breakdown) product of purine metabolism and is excreted in urine [12]. In human, $\mathrm{XO}$ is normally found in the liver and not free in the blood. During severe liver damage, XO is released into the blood, so a blood assay for XO is a way to determine if liver damage has happened. The goal of this study was to study XO activity and some factors affecting its activity, such as concentration of substrate hypoxanthine, concentration of the enzyme $\mathrm{XO}$ and $\mathrm{pH}$ of the medium, in patients to compare with control group, and to investigate the relationship of XO activity with nephrotic syndrome disorder in children, and the optimization of the enzyme activity conditions in the disorder. It may be useful for diagnosis and monitoring of the disease. 


\section{Material and Methods}

Hypoxanthine was purchased from Fluka, $\mathrm{Na}_{2} \mathrm{HPO}_{4}$ and $\mathrm{NaH}_{2} \mathrm{PO}_{4}$ were purchased from $\mathrm{BDH}$, Urate kit from Randox (UK), and Urea kit from Biomaghreb (Spain). All other chemicals were of analar grade.

\subsection{Selection of Criteria}

\subsubsection{Patient Group}

Sixty patients were diagnosed as having NS. They are untreated males and females, their ages ranged between $1-12$ years. They are attending the Central Children Teaching Hospital (CCTH) at Baghdad (IRAQ) during the period from $2^{\text {nd }}$ Mar. 2013 to $28^{\text {th }}$ Feb. 2014. All the patients were diagnosed by specialized physicians (nephrologists).

\subsubsection{Control Group}

Seventy normal volunteers, they have no any signs that suffering from any disease that may affect the study trial. Their ages were between $10-12$ years old.

\subsection{Collection of Blood Samples}

Five to ten $\mathrm{ml}$ of blood venous was collected into plain tube both NS and normal volunteers. Blood samples allowed to stand for $10 \mathrm{~min}$. at room temperature, then centrifuged at $3000 \mathrm{rpm}$. for $15 \mathrm{~min}$. then clot was isolated. Sera (yellowish in color) was separated and used for the determination of investigated parameters.

\subsection{Methods and Principles}

\subsubsection{Determination of XO-Activity}

The principle depends on catalysis of hydroxylation of hypoxanthine to xanthine and oxidation xanthine to uric acid in further step [13]. The rate of formation of urate from hypoxanthine is determined by measuring increased absorbance $(\mathrm{Ab})$ at $290 \mathrm{~nm}$. A unit of activity is defined as: forming one micromole of urate per minute at $25^{\circ} \mathrm{C}$ using UV-Visible spectrophotometer from CECIL7200 (UK).

\subsubsection{Determination of Urate Level}

Serum uric acid was determined by enzymatic assay using Biomaghreb kit [14]. The principle described the oxidation of uric acid to allantoin and hydrogen peroxide formation. Hydrogen peroxide in the presence of peroxidase reacts with a chromogen (amino-antipyrine and dichloro-hydroxy benzene sulphonate) to yield quinoneimine, a red colored complex. The absorbance measured at $520 \mathrm{~nm}$ (490 - 530) is proportional to the amount of uric acid in the specimen.

\subsubsection{Determination of Urea Level}

A colorimetric assay was applied using Randox kit [15]. The principle depends on the degradation of urea to ammonia and water then the product in presence of salicylate and hypochlorite resulted in the formation of green complex. 


\subsubsection{Effect of Hypoxanthine Different Concentration}

Different concentrations $(1,2,3,5,10,15,20,25,30 \mathrm{mM})$ of hypoxanthine were used to verify the best substrate concentrations that give maximum XO activity and complex formation. Same protocol of XO activity was adopted [12]. The analysis was applied for both NS and normal sera.

\subsubsection{Effect of XO Concentration}

Same protocol was adopted [16] and the only changes is that the assay applied using different serum volume $(10,25,50,75,100,125,150,200 \mu \mathrm{L})$, and the assay was applied for both NS and normal sera.

\subsubsection{Effect of pH Value}

Same protocol was adopted [12] in investigating the effect of $\mathrm{pH}$ on $\mathrm{XO}$ activity in both NS and normal sera, and the only exception was the use of different $\mathrm{pH}$ values $(5,5.5,6,6.5,7,7.5,7.8,8,9.2,11,12$, and 13$)$.

\subsection{Statistical Analysis}

SPSS version 22 for windows was used in the analysis of the data obtained. Statistical analysis was assessed using student $t$-test. Mean $\pm \mathrm{SD}$ value was adopted in the determinations. P-values less than 0.001 were considered statistically significant.

\section{Results}

\subsection{Xanthine Oxidase Activity}

Estimation of XO activity has been assayed (Table 1 ) and the results revealed significant elevation $(\mathrm{P}<0.001)$ in its activity in serum of NS patient $(0.12 \pm 0.06$ $\mathrm{IU} / \mathrm{L})$ compared with control $(0.05 \pm 0.09 \mathrm{IU} / \mathrm{L})$. The elevation was found to be $2 / 3(71 \%)$ than the control.

\subsection{Assay of Uric Acid and Urea}

Results in Table 2 showed the mean \pm SD of uric acid and urea in sera of both normal objects and NS patients. Highly significant $(P<0.001)$ elevation was found in uric acid compared with that in normal. A significant elevation $(\mathrm{P}$

Table 1. Demographic and clinical characteristics of the study population.

\begin{tabular}{cccc}
\hline Serum & NO. & Age (year) & XO Activity $(\mathrm{U} / \mathrm{mg})$ protein Mean $\pm \mathrm{SD}$ \\
\hline Normal & 60 & $1-12$ & $0.05 \pm 0.01$ \\
Nephrotic syndrome & 70 & $1-12$ & $0.12 \pm 0.01$ \\
P value & & & $<0.001$
\end{tabular}

Table 2. The Mean \pm S.D of Uric acid and Urea in sera of normal and NS patients.

\begin{tabular}{ccccc}
\hline Parameter & No. & Normal & Nephritic syndrome & P Value \\
\hline Uric acid $(\mathrm{u} \mathrm{mol} / \mathrm{L})$ & 41 & $298.12 \pm 1.7$ & $497 \pm 3.21$ & $<0.001$ \\
Urea $(\mathrm{u} \mathrm{mol} / \mathrm{L})$ & 70 & $4.57 \pm 1.27$ & $10.69 \pm 7.55$ & $<0.001$
\end{tabular}


$<0.001)$ was also found in studying the serum urea level in both normal and NS objects.

\subsection{Optimum Hypoxanthine Substrate Concentration}

Hypoxanthine was used as a substrate in the investigation of XO activity. Different concentrations of hypoxanthine were used to verify the appropriate concentrations that assure the Xo-Hypoxanthine complex formation through saturation of the enzyme active sites. A $10 \mathrm{mM}$ concentration was seen to achieve such saturation and formation of XO-Hypoxanthine complex, i.e., achieving XO activity. This was furnished using Michaelis-Menton study state analysis (a plot of velocity vs. different concentrations of hypoxanthine) (Figure 1) [17]. The maximum activity was observed at $\mathrm{pH} 7.5$ and maximum temperature of $25^{\circ} \mathrm{C}$ as best conditions for the catalyzed reaction of XO enzyme. This optimum hypoxanthine concentration $(10 \mathrm{mM})$ reflects the specificity of XO-enzyme in the catalyzed reaction.

\subsection{Effect of Increasing XO Concentration}

Using increased enzyme content, the activity of XO enzyme was found to increase linearly with increasing enzyme concentration (Figure 2). This linear relationship explained the direct proportional of the rate of enzyme-catalyzed reaction to the enzyme concentration under assay conditions [18].

\subsection{Effect of pH Value}

There are a number of distinct effects that a change in $\mathrm{pH}$ can have on enzyme catalyzed reactions, e.g. inactivation of the enzyme outside a certain $\mathrm{pH}$ range or a change in the ionization state of the substrate. A third possibility is that there could be a change in the equilibrium position if $\mathrm{H}^{+}$is involved in the reaction,

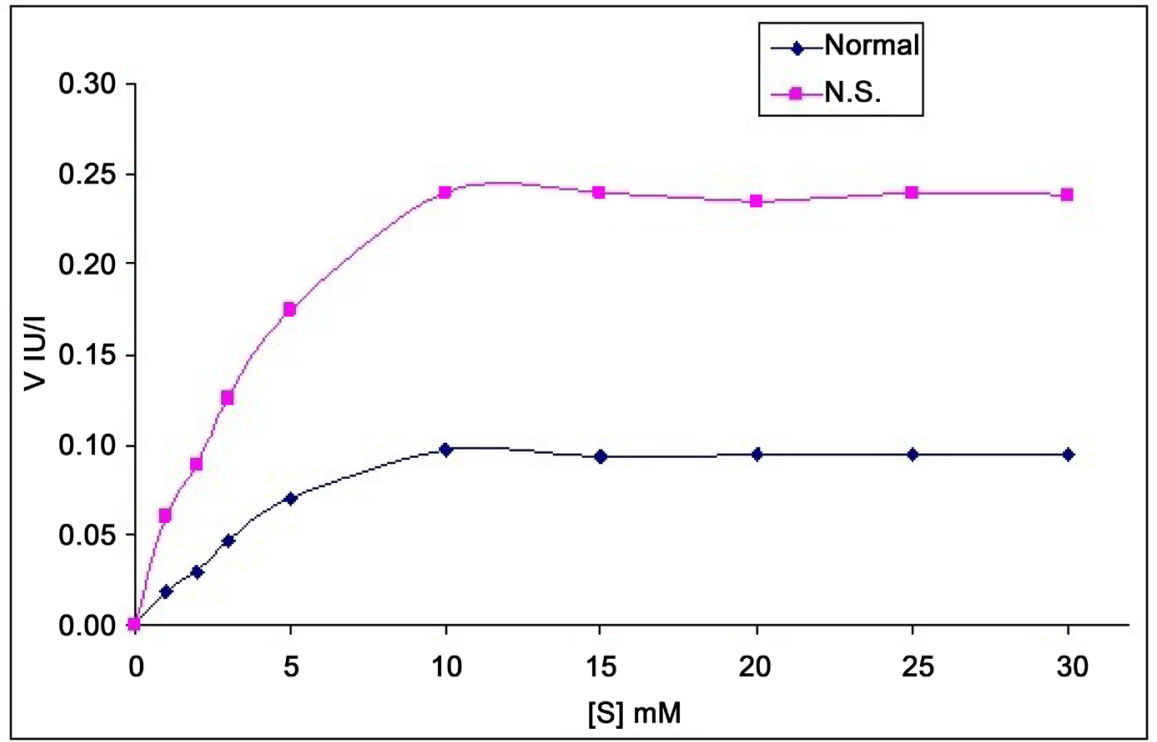

Figure 1. The effect of xanthine concentration on xanthine oxidase activity. 


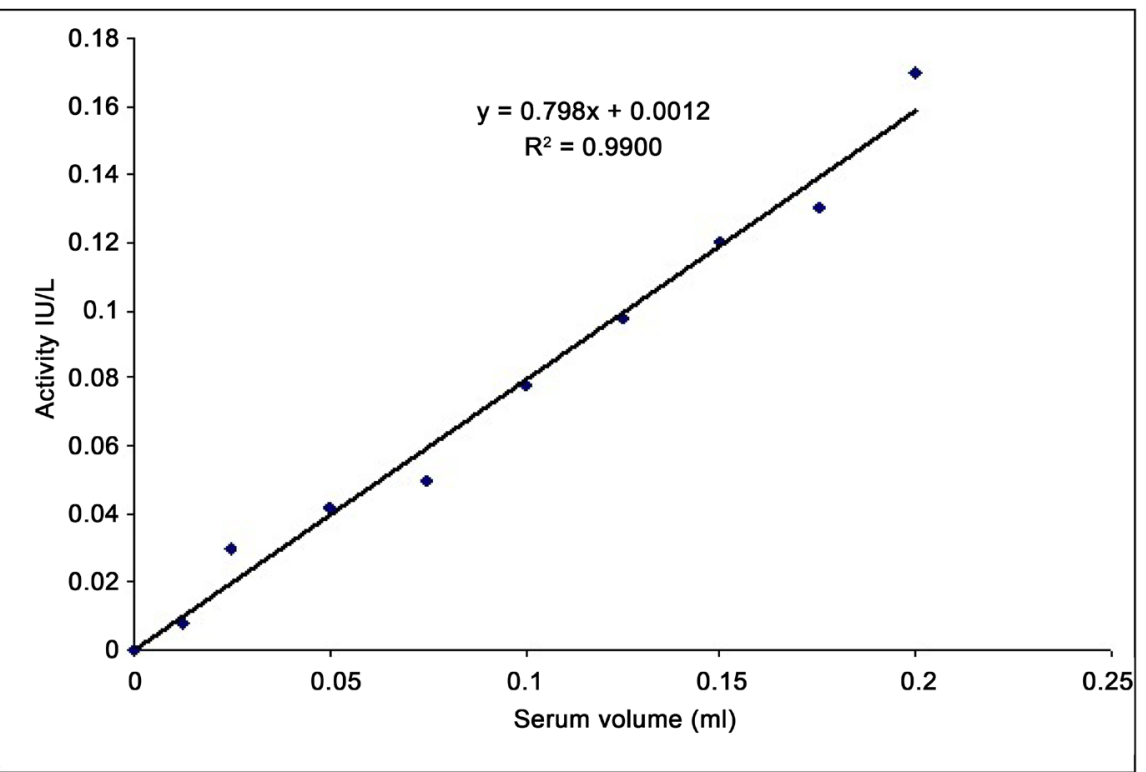

Figure 2. The effect of serum volume on xanthine oxidase activity.

e.g. in the reaction catalyzed by the enzyme. In this case, increasing the $\mathrm{pH}$ will displace the equilibrium in favors of product formation [18].

\section{Discussion}

Nephrotic syndrome divided into two main types; primary and secondary NS. Primary is caused by congenital defect of the kidney; while secondary NS it means other diseases affect the kidney. It is a common disorder characterized by alteration in permeability of the glomerular capillary wall, resulting in its inability to restrict the urinary loss of proteins, hypoalbuminemia, hyperlipidemia associated with peripheral edema [15]. A suggested explanation for such behavior is the possibility of reactive oxygen species (ROS) mediators of glomerular injury [16]. Thus, NS is regarded as a consequence of an imbalance between oxidants and antioxidants activity. It was observed that super-oxide mediated oxidative injury degrades the glomerular basement membrane and reduces de novo synthesis of proteoglycans that affects the glomerular permeability [19]. So that in an experiment in a complex rat model with chronic glomerulonephritis, it was suggested that induction of XO, with increased oxygen radical generation [20], was involved in aggravation of tubulointerstitial injury [21]. It was mentioned that XO could be a major cause of increased ROS generation, and it was found that the activity of this oxidase was two-to three-fold higher. Based on these results, XO dependent oxidative pathogenesis mechanisms could play an important role as mediator in renal damage, and which, in turn, facilitated the increased macrophage infiltration in the kidney [21] [22]. A recent research has concentrated on mechanisms to reduce the formation of ROS rather than a scavenging approach to already formed $\mathrm{ROS}^{21}$. Elevation in XO activity was also found in a subsequent follow-up study that found a significant benefit in pa- 
tients with high baseline urate, which could imply either high XO activity [23]. Increasing serum urea and uric acid in nephritic syndrome obtained by Dakshinamurty et al. (2002) [24] who used $\mathrm{mg} / \mathrm{L}$ as adopted units. A suggestion has been made that there could be minimal to gross impairment of renal function during the onset and progression of a kidney disease or renal disorder [25]. This impairment may range from subclinical to complete renal function. Blood biochemistry has been of great help in the assessment of renal function. Simultaneous increases in the levels of blood uric and urea have been observed during a variety of renal disorder [26]. The main feature of NS is that the kidney leak a lot of protein and urea is the end product of protein degradation. The main reason why fluid leaks out from the blood vessels into the body tissues with NS is because of a low level of protein in the blood. As protein is lost from the body in the urine, the body makes more protein in the liver which passes into the blood stream. However, intime the amount made by the liver cannot keep up with the amount lost by the kidneys, it is degraded to urea that elevated and so the blood level of protein goes down [27] [28]. It has been proved that urate levels are found to be elevated six-fold, reflecting accelerated purine oxidation during disease progress. Therefore $\mathrm{XO}$ production may not necessarily be reflected by systemic levels of XO metabolites [29]. States of high cell turnover and alcohol ingestion are the majority of cases of elevated serum uric acid, and the population distribution of level result from differences in renal excretion [17]. The $\mathrm{pH}$ has an effect on the tertiary structure of the enzyme, and therefore, on its activity, so that the enzyme may be irreversibly denatured at extreme $\mathrm{pH}$ value [18]. As it was clear (Figure 3), that XO-activity seems to be highly sensitive to the changes in $\mathrm{pH}$ of NS serum compared with control. This was observed from the sharp peak obtained in case of NS. The $\mathrm{pH}$ value between $6-7.5$ reflects the facts

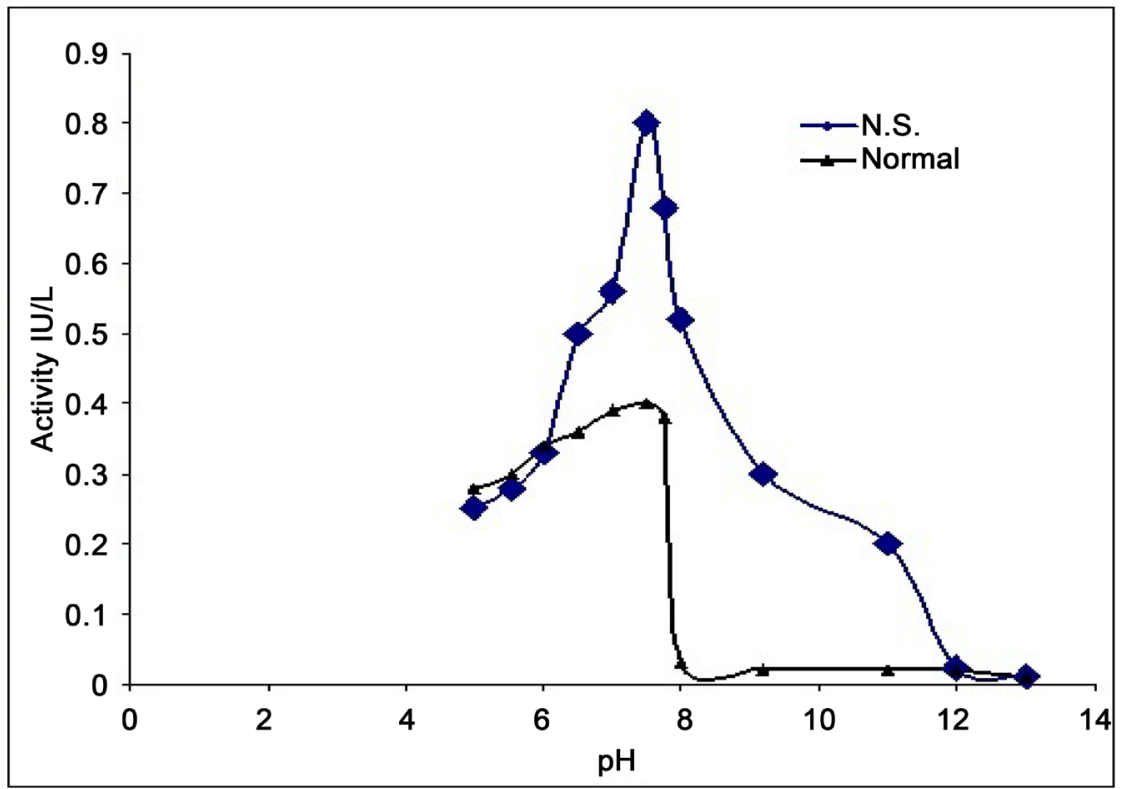

Figure 3. The effect of $\mathrm{pH}$ on xanthine oxidase activity. 
that denature in the complex formed could be occurred in control while in NS a slight resistance take place. Most obviously, increasing the $\mathrm{pH}$ value to (8), this was resulting in a deep prohibition in control XO-activity. Using $\mathrm{pH}$ value between $12-13$, the XO activity as seen reach zero value in both cases and this can be explained to be due to the probability of denaturation of the complex formed and/or the occurring of a re association of the complex [30].

\section{Conclusions}

The results can be concluded as:

1) Significant $(P<0.001)$ elevation in XO activity in serum of nephritic syndrome $(0.12 \pm 0.06 \mathrm{IU} / \mathrm{L})$ compared with that of normal subjects $(0.05 \pm 0.009$ $\mathrm{IU} / \mathrm{L})$.

2) Factors influencing $X O$ activities were also studied and showed that $X O$ activity is a pH dependent. Significant elevation $(\mathrm{P}<0.001)$ was found in uric acid level in sera of NS patients $(497.52 \pm 3.21 \mu \mathrm{mol} / \mathrm{L})$ compared with that in normal group $(298.12 \pm 1.70 \mu \mathrm{mol} / \mathrm{L})$

3) Elevation was found in urea level in sera of NS patient (10.69 \pm 7.55 $\mathrm{mmol} / \mathrm{L})$ compared with that of normal group $(4.57 \pm 1.27 \mathrm{mmol} / \mathrm{L})$.

\section{References}

[1] Davin, J.C., Tenberg, I.J. and Weening, J.J. (2001) What Is the Difference between IgA Nephropathy and Henoch-Schonlein Purpura Nephritis? Kidney International Journal, 59, 823-834.

[2] Niaudet, P. (2004) Steroid-Sensitive Nephrotic Syndrome in Children. In: Avner, E.D., Harmon, W.E. and Neasden, P., Eds., Paediatric Nephrology, Lippincott Williams and Wilkins, Philadelphia, 543-556.

[3] Kher, K., Schnaper, H.W. and Greenbaum, L.A. (1990) Clinical Pediatric Nephrology. 3rd Edition, CRC Press and Francis Group, Boca Raton, London, New York, 307.

[4] Kelly, C.R. and Landman, J. (2012) The Netter Collection of Medical Illustrations-Urinary System. Elsevier Health Sciences, Permissions for Netter Art Figures may be sought directly from Elsevier's Health Science Licensing, 101.

[5] Mendoza, S.A. and Tune, B.M. (1999) Treatment of Childhood Nephritic Syndrome. Journal of the American Society of Nephrology, 3, 889-894.

[6] Korbet, S.M., Schwartz, M.M. and Lewis, J.E. (1994) Primary Focal Segmental Glomerulosclerosis: Clinical Course and Response to Therapy. American Journal of Kidney Disease, 6, 773-783.

[7] Glassock, R.J. (1989) Proteinmia. In: Textbook of Nephrology, 2nd Edition, Williams \& Willkins, Baltimore, 189-197.

[8] Brenner, B.M. and Eger, N. (1978) No Evidence of Sevoflurance Induced Renal Injury in Volunteers. Journal of Medicine, 87, 230-231.

[9] Enorth, C., Eger, B.T., Okamoto, K., Nishino, T. and Pai, E.F. (2000) Crystal Structures of Bovine Milk Xanthine Dehydrogenase and Xanthine Oxidase: Structure-Based Mechanism of Conversion. PNAS, 97, 10723-10728. https://doi.org/10.1073/pnas.97.20.10723

[10] Metz, S. and Thiel, W. (2009) A Combined QM/MM Study on the Reductive 
Half-Reaction of Xanthine Oxidase: Substrate Orientation and Mechanism. Journal of the American Chemical Society, 131, 14885-14902. https://doi.org/10.1021/ja9045394

[11] Serafi, S.V., Taremi, C. and Osborn, M. (2011) Waves in a Hypothermic Patient. The Journal of Community Hospital Internal Medicine Perspectives, 1, No. 4.

[12] Battelli, M.G., Musiani, S., Valgimigli, M., Gramantieri, L., Tomassoni, F., Bolondi, L. and Stirpe, F. (2001) Serum Xanthine Oxidase in Human Liver Disease. The American Journal of Gastroenterology, 96, 1194-1199. https://doi.org/10.1111/j.1572-0241.2001.03700.x

[13] Heinz, F., Reckel, S. and Kalden, J.R. (1979) A New Spectrophotometric Assay for Enzymes of Purine Metabolism. Determination of Xanthine Oxidase Activity. Enzyme, 24, 239-246. https://doi.org/10.1159/000458665

[14] Tietz, N.W. (1999) Text Book of Clinical Chemistry. 3rd Edition, C.A. Burtis, E.R. Ashwood, W.B. Saunders, 1245-1250.

[15] Tiffany, T.O., Jansen, J.M., Burtis, C.A., Overtin, J.B. and Scott, C.D. (1972) Enzymatic Kinetic Rate and End-Point Analysis of Substrate Using a Gemasec Fast Analyzer. Clinical Chemistry, 18, 829-840.

[16] Klisic, J., Zhang, J., Nief, V., Reyes, L., Moe, O.W. and Ambuhl, P.M. (1972) Insulin Activates $\mathrm{Na}^{+} / \mathrm{H}^{+}$Exchanger 3: Biphasic Response and Glucocorticoid Dependence. Journal of the American Society of Nephrology, 29, 308-316.

[17] Lineweaver, H. and Burk, D. (1934) The Determination of Enzyme Dissociation constants. Journal of the American Chemical Society, 19, 658.

https://doi.org/10.1021/ja01318a036

[18] Price, N.C. and Stevens, L. (2003) Fundamentals of Enzymology: The Cell and Molecular Biology of Catalytic Proteins. 3rd Edition, Oxford University Press, New York, 133.

[19] Ande Walle, J.G., Donckerwolcke, R.A. and Koomans, H.A. (1999) Pathophysiology of Edema Formation in Children with Nephrotic Syndrome Not Due to Minimal Change Disease. Journal of the American Society of Nephrology, 10, 323-331.

[20] Duann, P., Datta, P.K., Pan, C., Blumberg, J.B., Sharma, M. and Lianos, E.A. (2006) Superoxide Dismutase Mimetic Preserves the Glomerular Capillary Permeability Barrier to Protein. Journal of Pharmacology and Experimental Therapeutics, 316, 1249-1254.

[21] Gwinner, W., Scheuer, H., Haller, H., Baandes, R.B. and Gronene, H.J. (2005) Pivotal Role of Xanthine Oxidase in the Initiation of Tubulointerstitial Renal Injury in Rats with Hyperlipidemia. Kidney International, 69, 481-487.

[22] George, J. and Struthers, A.D. (2009) Role of Urate, Xanthine Oxidase and the Effects of Allopurinol in Vascular Oxidative Stress. Vascular Health and Risk Management, 5, 265-275.

[23] Dakshinamurty, K.V., Srinivasa, P. V., Saibaba, K.S.S., Sheela, R.B. and Venkataramana, G. (2002) Antioxidant Status in Patients on Maintenance Haemodialysis. Indian Journal of Nephrology, 57, 77-80.

[24] Ni, Z. and Vaziri, N.D. (2003) Downregulation of Nitric Oxide Synthase in Nephrotic Syndrome: Role of Proteinuria. Biochimica et Biophysica Acta, 1638, 129-137.

[25] Hamm, L.L. and Batuman, V. (2003) Edema in the Nephritic Syndrome: New Aspect of an Old Engima. Journal of the American Society of Nephrology, 14, 3288-3289. https://doi.org/10.1097/01.ASN.0000102671.77794.33

[26] Hodson, E., Willis, N. and Craig, J. (2007) Corticosteroid Therapy for Nephrotic 
Syndrome in Children. The Cochrane Database of Systematic Reviews, 17, 1533.

[27] George, J., Carr, E., Davies, J., Belch, J.J.F. and Struthers, A. (2006) High-Dose Allopurinol Improves Endothelial Function by Profoundly Reducing Vascular Oxidative Stress and Not by Lowering Uric Acid. Circulation, 114, 2508-2516. https://doi.org/10.1161/CIRCULATIONAHA.106.651117

[28] Baldus, S., Koster, R., Chumley, P., Heitzer, T., Rudolph, V. and Ostad, M.A. (2005) Oxypurinol Improves Coronary and Peripheral Endothelial Function in Patients with Coronary Artery Disease. Free Radical Biology \& Medicine, 31, 1184-1190. https://doi.org/10.1016/j.freeradbiomed.2005.06.004

[29] Higgins, P., Dawson, J. and Walters, M. (2009) The Potential for Xanthine Oxidase Inhibition in the Prevention and Treatment of Cardiovascular and Cerebrovascular Disease. Cardiovascular Psychiatry and Neurology, 28, 59.

[30] Brown, E.A. (1985) The Nephrotic Syndrome. Postgraduate Medical Journal, 61, 1057-1062. https://doi.org/10.1136/pgmj.61.722.1057 